\title{
UJI AKTIVITAS ANTIBAKTERI EKSTRAK ETANOL UMBI PAKU ATAI MERAH (Angiopteris ferox Copel) TERHADAP Propionibacterium acnes
}

\section{ANTIBACTERY ACTIVITY TEST OF ETHANOL EXTRACT OF RED PAKU ATAI TUBER (Angiopteris ferox Copel) on Propionibacterium acnes}

\author{
Reksi Sundu, Sapri, Fitri Handayani \\ Akademi Farmasi Samarinda \\ Jl. Brig. Jend. Abdul Wahab Sjahranie No. 226, Air Hitam, Samarinda \\ Email:reksi.sundu@gmail.com,085248667713
}

Submitted : 8 Maret 2018

Reviewed : 9 Maret 2018 Accepted : 30 Maret 2018

\begin{abstract}
ABSTRAK
Kalimantan adalah pulau yang memiliki keanekaragaman hayati dan potensi yang sangat melimpah sebagai tumbuhan berkhasiat obat. Masyarakat suku dayak daerah Kutai Barat di Kecamatan Linggang Bigung Kalimantan Timur menggunakan paku atai merah sebagai obat dengan cara umbi paku atai merah diparut dan dicampur dengan beras kemudian diolah menjadi bedak dingin untuk kulit yang berjerawat. Tujuan penelitian untuk mengetahui aktivitas antibakteri pada ekstrak etanol umbi paku atai merah terhadap Propionibacterium acnes. Penelitian diawali dengan skrining fitokimia yaitu pemeriksaan senyawa golongan alkaloid, flavanoid, saponin, tanin dan steroid/terpenoid selanjutnya dilakukan pengujian aktivitas antibakteri terhadap Propionibacterium acnes dengan metode difusi cakram. Larutan uji dibuat dengan konsentrasi yang berbeda yaitu ekstrak etanol umbi paku atai merah $20 \%, 40 \%, 60 \%$ dan $80 \%$, kontrol positif clindamycin $0,1 \%$, kontrol negatif DMSO $0,1 \%$. Metode analisis data adalah metode deskriptif yaitu berupa data kualitatif dan kuantitatif. Data disajikan dalam bentuk tabel dan gambar. Hasil skrining fitokimia menunjukkan positif mengandung golongan alkoloid, flavonoid, tanin, saponin dan steroid. Hasil pengujian aktivitas antibakteri menunjukkan bahwa ekstrak etanol umbi paku atai merah memiliki aktvitas antibakteri terhadap Propionibacterium acne dengan diameter zona hambat sebesar 6,83mm $\pm 0,27(20 \%) ; 8,33 \mathrm{~mm} \pm 0,36(40 \%)$ dan $8,25 \mathrm{~mm} \pm 0,31(80 \%)$ yaitu zona hambat kategori sedang. Ekstrak etanol $60 \%$ menunjukkan zona hambat bakteri $11,05 \mathrm{~mm} \pm 1,99$ yaitu zona hambat kategori kuat. Clindamycin $0,1 \%$ memiliki zona hambat bakteri $24,10 \mathrm{~mm} \pm 0.61$ yaitu zona hambat kategori sangat kuat. Dimetil sulfoksida $0,1 \%$ tidak memiliki daya hambat bakteri.
\end{abstract}

Kata kunci : Paku atai merah, Angiopteris ferox Copel, umbi, antibakteri, Propionibacterium acnes 


\begin{abstract}
Borneo is an island that has biodiversity and abundant potential of medicinal plants. The Dayak tribe of West Kutai area in sub-district Linggang Bigung of East Kalimantan use red paku atai as medicine. It is processed by shredded and mixed with rice and then processed into cold powder for acne prone skin. The objective of this study was to investigate antibacterial activity on ethanol extract of red paku atai tuber on Propionibacterium acnes. The research was started with phytochemical screening, i.e. examination of compound of alkaloid, flavonoid, saponin, tannin and steroid / terpenoid and then tested the antibacterial activity on Propionibacterium acnes by disc diffusion method. The test solution was prepared with different concentrations, i.e. ethanol extract of red paku atai tuber of $20 \%, 40 \%, 60 \%$ and $80 \%$, clindamycin positive control of $0.1 \%$, negative control of DMSO of $0.1 \%$. Data analysis method was descriptive method that was in the form of qualitative and quantitative data. Data was presented in the form of tables and drawings. The results of phytochemical screening showed positively containing alkaloid, flavonoids, tannins, saponins and steroids. The result of antibacterial activity test shows that ethanol extract of red paku atai tuber with concentration of $20 \%, 40 \%, 60 \%$ and $80 \%$ have antibacterial activity on Propionibacterium acnes. The ethanol extract of red paku atai tuber shows a bacterial inhibitory zone of 6,83mm $\pm 0,27(20 \%) ; 8,33 \mathrm{~mm} \pm 0,36(40 \%)$, and 8,25 $\mathrm{mm} \pm 0,31(80 \%)$ i.e. medium category inhibitory zone. $60 \%$ ethanol extract shows 11,05 $\mathrm{mm} \pm 1.99$ inhibit zone, i.e. strong category. Clindamycin $0.1 \%$ has a bacterial inhibition zone of $24,10 \pm 0,61 \mathrm{~mm}$ i.e. very strong category inhibitory zone. Dimethyl sulfoxide $0,1 \%$ $\pm 0,00$ does not have bacterial inhibition.
\end{abstract}

Keywords : red paku atai, Angiopteris ferox Copel, tubers, antibacterial, Propionibacterium acnes

\title{
PENDAHULUAN
}

Tumbuhan paku merupakan salah satu golongan tumbuhan yang hampir dapat dijumpai pada setiap wilayah di Indonesia. Tumbuhan paku telah banyak dimanfaatkan antara lain sebagai tanaman hias, sayuran dan bahan obat-obatan. Berdasarkan tempat hidupnya, tumbuhan paku ditemukan tersebar luas mulai daerah tropis hingga dekat kutub utara dan selatan. Mulai dari hutan primer, hutan sekunder, alam terbuka, dataran rendah hingga dataran tinggi, lingkungan yang lembab, basah, rindang, kebun tanaman, pinggir jalan paku dapat dijumpai (Arini, 2012).

Kalimantan adalah pulau yang memiliki tingkat keanekaragaman hayati yang sangat melimpah memiliki potensi sebagai tumbuhan yang berkhasiat obat, salah satu tanaman yang dimanfaatkan sebagai obat oleh suku dayak adalah tumbuhan paku atai merah (Angiopteris ferox Copel) yang digunakan sebagai obat. Pada penelitian sebelumnya (Mismawati, 2015) melaporkan bahwa ekstrak methanol daun Angiopteris evecta memiliki kemampuan menghambat Sallmonela thypi $(11,22 \mathrm{~mm} \pm 1,02)$; Propionibacterium acnes $(10,22 \mathrm{~mm} \pm 1,26)$ dan Bacillus cereus $(10,30 \mathrm{~mm} \pm 0,00)$.

Secara empiris masyarakat Kutai Barat di Kecamatan Linggang Bigung Kalimantan Timur menggunakan paku atai merah sebagai obat yang berpotensi sebagai antikanker payudara dan sebagai antiracun. Bagian paku atai merah yang digunakan oleh suku dayak yang berada di daerah tersebut adalah bagian daun, batang, getah dan umbi. Daun dan batang paku atai merah yang masih segar diolah dengan cara direbus dan diminum airnya. Umbinya yang masih segar diparut dan dicampur dengan beras diolah menjadi bedak dingin yang digunakan untuk kulit yang berjerawat atau umbi yang masih segar dapat diseduh dengan air 
panas atau diminum air rebusannya, sedangkan getahnya bisa langsung digunakan dengan cara dioleskan pada bagian permukaan kulit tubuh yang terasa sakit.

Mengingat penelitian tentang aktivitas antibakteri paku atai merah dan besarnya potensi yang dimiliki tumbuhan paku atai merah belum pernah dilaporkan, maka akan dilakukan penelitian tentang uji aktivitas antibakteri ekstrak etanol umbi paku atai merah (Angiopteris ferox Copel) terhadap Propionibacterium acnes. Hasil penelitian ini diharapkan dapat memberikan informasi dalam pengembangan penelitian yang akan datang.

\section{METODE PENELITIAN}

\section{Alat dan Bahan}

Alat yang digunakan yaitu maserator, waterbath, rotary evaporator, LAF (Laminar Air Flow) inkubator, autoklaf, micro pipet, kertas cakram, jangka sorong.

Bahan yang digunakan adalah ekstrak umbi paku atai merah, aquadest, kloralhidrat, asam klorida $2 \mathrm{~N}$, asam asetat anhidrat, asam sulfat pekat, besi (III) klorida $1 \%$, etanol $70 \%$, pereaksi meyer, pereaksi bouchardat, pereksi dragendrof, nutrient agar (NA), klindamisin $0,1 \%$, dimetil sulfoksida (DMSO) $0,1 \%$, bakteri Propionibacterium acnes.

\section{Jalannya Penelitian}

1. Pembuatan Ekstrak Etanol Umbi Paku Atai Merah

Ekstrak dibuat dengan metode maserasi menggunakan pelarut etanol 70\%. Simplisia kering ditimbang sebanyak 300 gram kemudian dimasukan ke dalam wadah dan ditambahkan 3 L pelarut etanol 70\%. Didiamkan selama 24 jam sambil sesekali diaduk selama 6 jam pertama, selanjutnya dibiarkan selama 18 jam. Simplisia yang tercampur dalam etanol dimaserator selama 2 jam, didiamkan 30 menit kemudian disaring. Filtrat disisihkan, ampas dimaserasi dengan $1 \mathrm{~L}$ penyari etanol $70 \%$. Hasil remaserasi dimaserator kembali selama 2 jam kemudian disaring. Filtrat hasil maserasi dikentalkan denga rotary evaporator kemudian diuapkan di atas waterbath sampai diperoleh ekstrak kental.

2. Skrining Fitokimia

Skrining fitokimia dilakukan terhadap ekstrak etanol umbi paku atai merah yang meliputi : pemeriksaan senyawa kimia golongan alkaloid, flavanoid, saponin, tanin dan steroid/terpenoid (Harbone, 2006).

a. Uji Alkaloid

Sebanyak 3 gram sampel ditambah $10 \mathrm{ml}$ larutan amonia-kloroform0,05N kemudian campuran dikocok selama satu menit, kemudian disaring kedalam tabung reaksi. Terhadap filtrat tersebut ditambahkan $5 \mathrm{ml} \mathrm{H} 2 \mathrm{SO} 4$ dan dikocok dengan teratur, didiamkan sampai terbentuk dua lapisan. Lapisan atas (fase air) dipisahkan dan diuji dengan pereaksi Meyer dan Wagner.

b. Uji flavonoid

Sebanyak 2 gram sampel dimasukkan ke dalam becker glass dan ditambah dengan $20 \mathrm{ml}$ aquades kemudian dididihkan lalu disaring. Sebanyak $0,5 \mathrm{ml}$ filtrat ditambahkan $5 \mathrm{ml}$ ammonia encer dan $5 \mathrm{ml}$ asam sulfat pekat dan diamati.

c. Uji Saponin

Ke dalam beacker glass dimasukkan serbuk sampel sebanyak 2 gram, lalu ditambah dengan $20 \mathrm{ml}$ Aquades kemudian dididihkan lalu disaring. Diambil $10 \mathrm{ml}$ filtratnya dan ditambahkan $5 \mathrm{ml}$ aquades kemudian dikocok kuat hingga terbentuk busa. Lalu busanya ditambahkan 3 tetes minyak zaitun, setelah itu dikocok kembali dan diamati terbentuknya emulsi.

d. Uji Tanin

Ke dalam becker glass dimasukkan sebanyak 0,5 gram serbuk sampel, kemudian ditambahkan $20 \mathrm{ml}$ aquades lalu dididihkan dan disaring. Setelah itu sebanyak 
$0,5 \mathrm{ml}$ filtrat ditambahkan ferriklorida $0,5 \mathrm{ml}, 0,1 \%$ dan diamati terjadinya perubahan warna.

e. Uji Steroid

Ke dalam becker glass dimasukkan 2 gram sampel ditambah dengan $20 \mathrm{ml}$ metanol yang mengandung $2 \mathrm{ml}$ asam sulfat dididihkan dan disaring, setelah itu ditambahkan $2 \mathrm{ml}$ asam asetat anhidrat, lalu diamati perubahannya.

3. Pengujian Aktivitas Antibakteri

Pengujian aktivitas antibakteri dilakukan dengan metode difusi kertas cakram (Jawetz dkk, 2005). Sebanyak $100 \mu \mathrm{L}$ suspensi bakteri Propionibacterium acnes dituang secara merata pada medium Nutrient Agar (NA) yang telah diletakkan dalam cawan petri steril, kemudian diratakan sampai memenuhi semua permukaan media (Aziz, 2010). Setelah mengering, lalu diletakkan kertas cakram yang telah dijenuhkan dengan $10 \mu \mathrm{L}$ ekstrak etanol umbi paku atai merah dengan berbagai konsentrasi yaitu 20\%, 40\%, 60\% dan $80 \%$. Kontrol positif yang digunakan adalah klindamisin $0,1 \%$ dan kontrol negatif adalah DMSO $0,1 \%$. Media yang sudah berisi bakteri uji, larutan uji, kontrol positif dan kontrol negative kemudian diinkubasi pada suhu $37^{\circ} \mathrm{C}$ selama $24-48$ jam, setelah diinkubasi dilakukan pengukuran diameter zona hambat. Pengukuran diameter zona hambat dilakukan dengan menggunakan jangka sorong dan dilakukan pengulangan sebanyak 3 kali (Lay, 1994).

\section{Analisis Data}

Metode analisis data yang digunakan adalah metode deskriptif yaitu berupa data kualitatif dan kuantitatif. Data disajikan dalam bentuk tabel dan gambar.

\section{HASIL DAN PEMBAHASAN}

\section{Skrining Fitokimia}

Skrining fitokima menunjukkan bahwa ekstrak etanol umi paku atai merah mengandung metabolit sekunder sesuai dengan yang ditunjukan pada tabel I.

\section{Tabel I. Hasil Skrining Fitokimia Ekstrak Etanol Umbi Paku Atai Merah}

\begin{tabular}{cc}
\hline Metabolit Sekunder & Hasil \\
\hline Alkaloid & + \\
Flavonoid & + \\
Tanin & + \\
Saponin & + \\
Steroid & + \\
\hline
\end{tabular}

Keterangan :

+ : Menunjukan reaksi positif

2. Pengujian Aktivitas Antibakteri

Pengujian aktivitas antibakteri Propionibacterium acnes dilakukan pada 3 konsentrasi ekstrak etanol umbi paku atai merah yaitu $20 \%, 40 \%, 60 \%$ dan $80 \%$, klindamisin $0,1 \%$ sebagai kontrol positif, DMSO 0,1\% sebagai kontrol negatif. Terbentuknya zona bening (jernih) di sekitar kertas cakram pada uji aktivitas antibakteri membuktikan bahwa ekstrak etanol umbi paku atai merah memiliki sifat antibakteri terhadap Propionibacterium acnes. Hasil pengujian aktivitas antibakteri ekstrak etanol umbi paku atai merah terhadap Propionibacterium acnes dapat dilihat pada tabel II dan gambar 1 sebagai berikut : 
Tabel II. Hasil Pengukuran Zona Hambat $(\mathbf{m m})$ terhadap Propionibacterium acnes

\begin{tabular}{|c|c|c|c|c|}
\hline \multirow[t]{2}{*}{ Konsentrasi Ekstrak } & \multicolumn{3}{|c|}{ Diameter Zona Hambat (mm) } & \multirow{2}{*}{$\begin{array}{c}\text { Rata-rata } \\
(\mathrm{mm})\end{array}$} \\
\hline & 1 & 2 & 3 & \\
\hline $20 \%$ & 6,90 & 6,54 & 7,07 & $6,83 \pm 0,27$ \\
\hline $40 \%$ & 8,12 & 8,14 & 8,75 & $8,33 \pm 0,36$ \\
\hline $60 \%$ & 9,85 & 13,35 & 9,95 & $11,05 \pm 1,99$ \\
\hline $80 \%$ & 8,01 & 8,60 & 8,15 & $8,25 \pm 0,31$ \\
\hline Klindamisin $0,1 \%(+)$ & 23,70 & 24,80 & 23,80 & $24,10 \pm 0,61$ \\
\hline DMSO $0,1 \%(-)$ & 0 & 0 & 0 & $0 \pm 0,00$ \\
\hline
\end{tabular}

Data pada tabel II dan gambar 1 diketahui bahwa ketiga konsentrasi ekstrak etanol umbi paku atai merah mampu menghambat pertumbuhan Propionibacterium acne. Daya hambat menurut Davis dan Stous (1971) terbagi dalam kategori sangat kuat (zona jernih $>20$ $\mathrm{mm}$ ), kuat (zona jernih 10-20 mm), sedang (zona jernih 5-10 $\mathrm{mm}$ ) dan lemah (zona jernih < $5 \mathrm{~mm})$.

Konsentrasi ekstrak etanol 20\%, 40\% dan $80 \%$ memiliki daya hambat kategori sedang. Konsentrasi ekstrak etanol $60 \%$ memiliki daya hambat kategori kuat. Kontrol positif memiliki daya hambat kategori sangat kuat. Kontrol negatif tidak terbentuk adanya zona jernih. Hal ini menunjukkan bahwa DMSO 0,1\% tidak mempunyai sifat antibakteri terhadap pertumbuhan bakteri Propionibacterium acnes.

Metabolit sekunder yang terkandung pada ekstrak etanol umbi paku atai merah seperti alkoloid, flavonoid, tanin, saponin dan steroid/terpenoid memberikan daya hambat pertumbuhan Propionibacterium acnes.

Menurut Gunawan (2008) gugus basa yang mengandung nitrogen dapat menyebabkan keaktifan biologis dari senyawa alkaloid. Bakteri yang apabila kontak dengan gugus basa akan bereaksi dengan senyawa-senyawa asam amino yang menyusun dinding sel bakteri dan juga DNA bakteri yang merupakan penyusun utama inti sel yang merupakan pusat pengaturan segala kegiatan sel. Reaksi ini terjadi karena secara kimia suatu senyawa yang bersifat basa akan bereksi dengan senyawa asam dalam hal ini adalah asam amino karena sebagian besar asam amino telah beraksi dengan gugus basa dari senyawa alkaloid. Perubahan susunan asam amino ini jelas akan merubah keseimbangan genetik pada asam DNA sehingga DNA bakteri akan mengalami kerusakan . Kerusakan DNA pada inti sel bakteri akan mendorong terjadinya lisis pada inti sel, sehingga akan terjadi kerusakan sel. Kerusakan sel mengakibatkan sel-sel bakteri tidak mampu melakukan metabolisme sehingga akan mengalami lisis (hancur). Alkaloid dalam menghambat pertumbuhan bakteri dengan cara mengganggu komponen penyusun peptidoglikan pada sel bakteri, sehingga lapisan dinding sel tidak terbentuk secara utuh dan menyebabkan kematian sel tersebut (Robinson, 1995). Menurut Brooks, dkk (2005) bakteri mempunyai lapisan luar yaitu dinding sel. Dinding sel berfungsi untuk mempertahankan bentuk mikroorganisme dan pelindung sel bakteri yang mempunyai tekanan osmotik internal yang tinggi. Tekanan internal tersebut tiga hingga lima kali lebih besar pada bakteri gram positif dari pada gram negatif. Trauma pada dinding sel atau penghambatan pembentukannya menimbulkan lisis pada sel. 
Uji Aktivitas Antibakteri Ekstrak Etanol Umbi Paku Atai Merah ..... (Reksi Sundu)

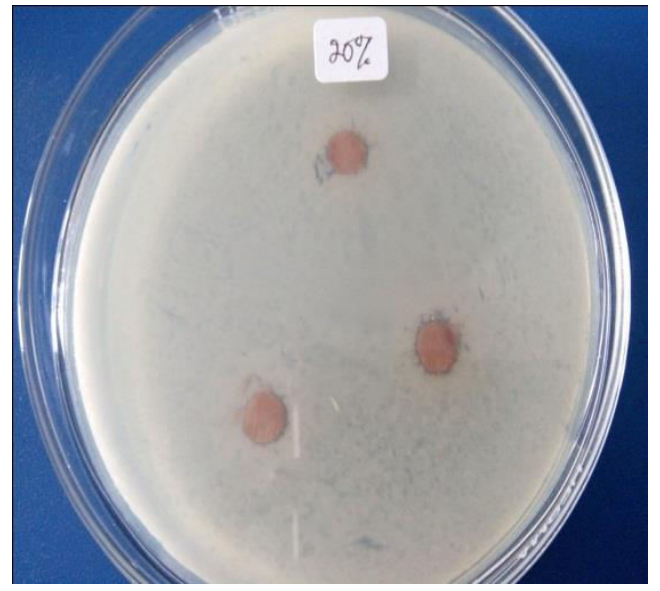

a
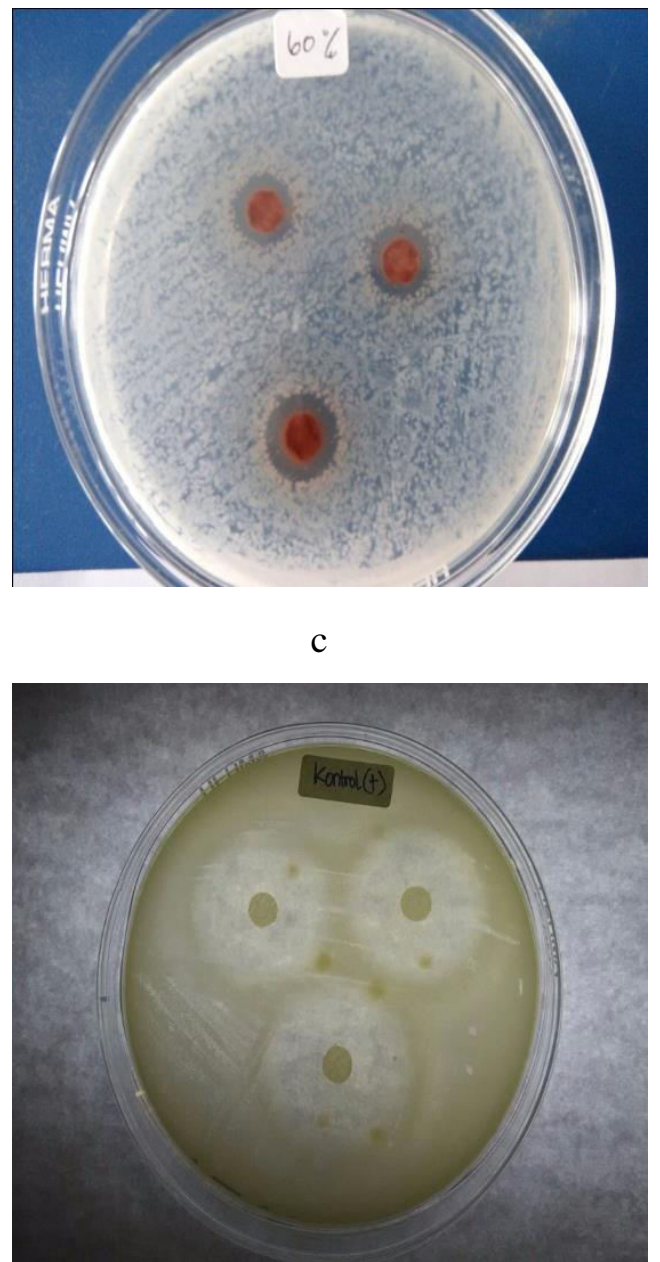

e

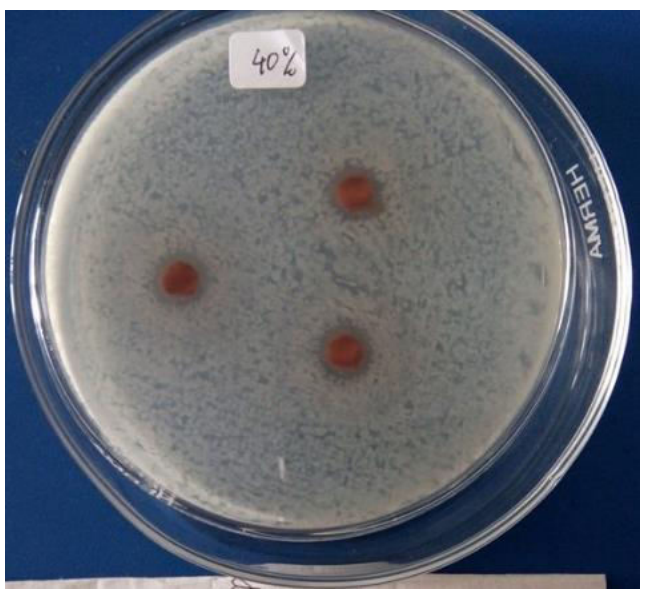

b

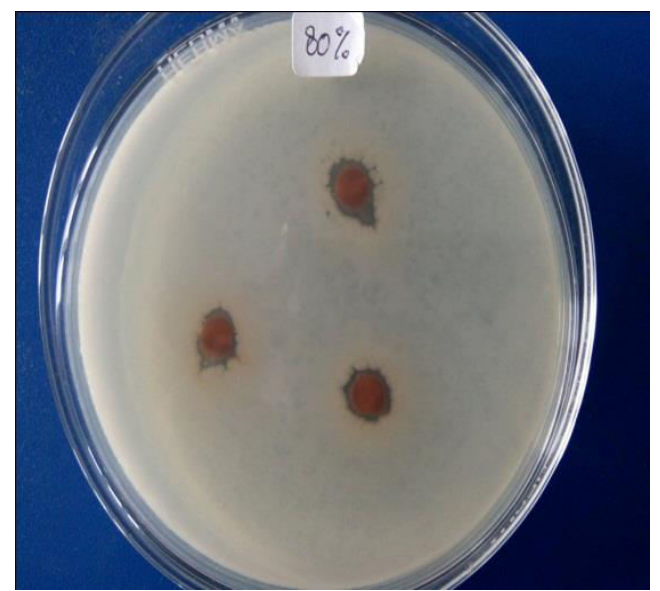

d

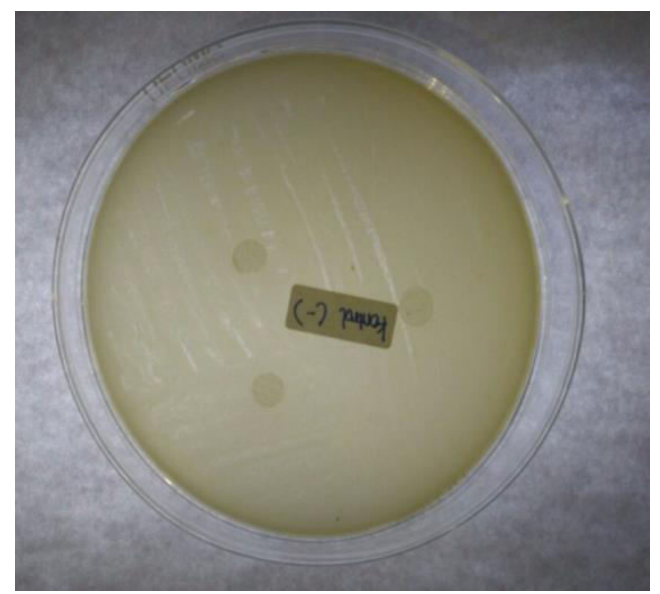

$\mathrm{f}$

Gambar 1.Hasil Uji Aktivitas Antibakteri terhadap Propionibacterium acnes

Keterangan :

a : zona hambat pada konsentrasi $20 \%$

b : zona hambat pada konsentrasi $40 \%$

c : zona hambat pada konsentrasi $60 \%$ $\mathrm{d}$ : zona hambat pada konsentrasi $80 \%$

e : zona hambat pada kontrol positif

f : zona hambat pada kontrol negatif 
Flavonoid membunuh bakteri dengan menyebabkan terjadinya kerusakan permeabilitas dinding sel bakteri, mikrosom dan lisosom sebagai interaksi antara flavonoid dengan DNA bakteri (Sabir, 2005). Mekanisme flavonoid sebagai antibakteri adalah membentuk senyawa kompleks dengan protein ekstraseluler dan terlarut yang mengakibatkan fosfolipid tidak mampu mempertahankan bentuk membran sel akan bocor dan bakteri akan mengalami hambatan pertumbuhan bahkan kematian (Robinson, 1995).

Tanin dapat mengkerutkan dinding sel atau membran sel sehingga menggangu permeabilitas sel itu sendiri, akibat terganggunya permeabilitas, sel tidak dapat melakukan aktivitas hidup sehingga pertumbuhannya terhambat (Ajizah, 2004). Mekanisme kerja tanin sebagai antibakteri adalah mengganggu sintesa peptidoglikan sehingga pembentukan dinding sel menjadi kurang sempurna. Keadaan tersebut akan menyebabkan sel bakteri menjadi lisis karena tekanan osmotik maupun fisik sehingga sel bakteri menjadi mati (Robinson, 1995). Tanin mampu menghambat pertumbuhan bakteri dengan cara menginaktivasi adhesi mikroba, enzim dan protein transport pada membran sel (Hamdiyati dkk, 2008). Masduki (1996) menyatakan bahwa tanin juga mempunyai daya antibakteri dengan cara mempresipitasi protein, karena diduga tanin mempunyai efek yang sama dengan senyawa fenolik. Efek antibakteri tanin antara lain melalui : reaksi dengan membran sel, inaktivasi enzim dan destruksi atau inaktivasi fungsi materi genetik.

Saponin menurunkan tegangan permukaan sehingga mengakibatkan naiknya permeabilitas atau kebocoran sel dan mengakibatkan senyawa intraseluler keluar (Robinson, 1995). Mekanisme kerja saponin sebagai antibakteri adalah menurunkan tegangan permukaan sehingga mengakibatkan naiknya permeabilitas atau kebocoran sel dan mengakibatkan senyawa intra seluler keluar.

Senyawa steroid/triterpenoid juga memiliki potensi sebagai senyawa antibakteri. Senyawa steroid/triterpenoid menghambat pertumbuhan bakteri dengan mekanisme penghambatan terhadap sintesis protein karena terakumulasi dan menyebabkan perubahan komponen-komponen penyusun sel bakteri itu sendiri. Senyawa terpenoid mudah larut dalam lipid sifat inilah yang mengakibatkan senyawa ini lebih mudah menembus dinding sel bakteri Gram positif dan sel bakteri Gram negatif (Rosyidah dkk., 2010). Steroid/terpenoid adalah senyawa organik lemak sterol tidak terhidrolisis yang dapat dihasilkan dari reaksi penurunan dari terpena atau skualena steroid membunuh bakteri dengan cara merusak membran sel bakteri (Zaenglein dkk, 2016).

\section{KESIMPULAN}

Dari hasil investigasi diatas dapat disimpulkan bahwa ekstrak etanol umbi paku atai merah memiliki aktvitas antibakteri terhadap Propionibacterium acnes.

\section{DAFTAR PUSTAKA}

Mismawati, A., Srisuwannaket, C., Mingvanish, W., Kuspradini, H., Kusuma, W.K., Niamnot, 2015, Phytochemcal Screening and Bioactivity of Angiopteris evecta Leaves From East Kalimantan. Proceeding "Innovative Chemistry For Sustainability of The AEC and Beyond". Bangkok, 21-23 Januari 2015.

Ajizah, A., 2004, Sensitivitas Salmonella Typhimurium terhadap Ekstrak Daun Psidium Guajava L, Jurnal Bioscientiae, Vol. I No 1. 31-38

Arini, Diah, I.D \& Kinho, Julianus. 2012. Keragaman Jenis Tumbuhan Paku (Pteridophyta) Di Cagar Alam Gunung Ambang Sulawesi Utara. Balai Penelitian Kehutanan Manado. Info BPK Manado, Vol. 2 No. 1, Juni 2012

Aziz, S., 2010. Uji Aktivitas Antibakteri Ekstrak Etanol Daun dan Umbi Bakung Putih (Crinum asiaticum L.) Terhadap Bakteri Penyebab Jerawat. Skripsi. Program Studi Farmasi. Fakultas Kedokteran dan Ilmu Kesehatan. UIN Syarif Hidayatullah. Jakarta Brooks, G.F., Butel, J.S., Morse, S.A., 2005. Mikrobiologi Kedokteran. Salemba Medika. Jakarta. 
Davis, W.W. \& Stout, T.R., 1971, Disc Plate Method of Microbiological Antibiotic Assay, Factors Influencing Variability and Error, Applied Microbiology American Society for Microbiology, 22 (4), 659-665.

Gunawan. 2008. Antibakteri pada herba Meniran (Phylanthus niruri Linn). Jurnal Kimia, Vol II (22), hal.31-39

Hamdiyati, Yanti, Kusnadi, dan Irman Rahadian. Aktivitas Antibakteri Ekstrak Daun Patikan Kebo (Euphorbia hirta) terhadap Pertumbuhan Bakteri Staphylococcus epidermidis. FPMIPA UPI: Bandung.

Harborne, J. (2006). Metode Fitokimia. Bandung: ITB

Jawetz, E., J.L. Melnick dan E.A. Adelberg. 2005. Mikrobiologi untuk Profesi Kesehatan Edisi 4. Diterjemahkan oleh Bonang, G. Jakarta : Penerbit Buku Kesehatan

Lay, B. W. 1994. Analisis Mikroba di Laboratorium. PT. Rajagrafindo Persada, Jakarta.168

Masduki I, 1996. Efek Antibakteri Ekstrak Biji Pinang (Areca catechu) terhadap S. aureus dan E. coli. Cermin Dunia Kedokteran 109: 21-24.

Robinson, T. 1995. Kandungan Organik Tumbuhan Tinggi. Penerbit ITB. Bandung

Rosyidah, K., Nurmuhaimina, Komari, M.D., Astuti. 2010. Aktivitas Antibakteri Fraksi Saponin dari Kulit Batang Tumbuhan Kasturi Mangifera casturi. Jurnal Bioscientiae, 7 (2): 25-31.

Sabir, A, 2005, Aktivitas antibakteri flavonoid propolis Trigona sp terhadap bakteri Streptococcus mutans (in vitro), Dental journal, 38 (3):135- 141.

Zaenglein, Andrea L dkk. 2016. Guadlines of Care for The Management of Acne Vulgaris. American Academy of Dermatology. 